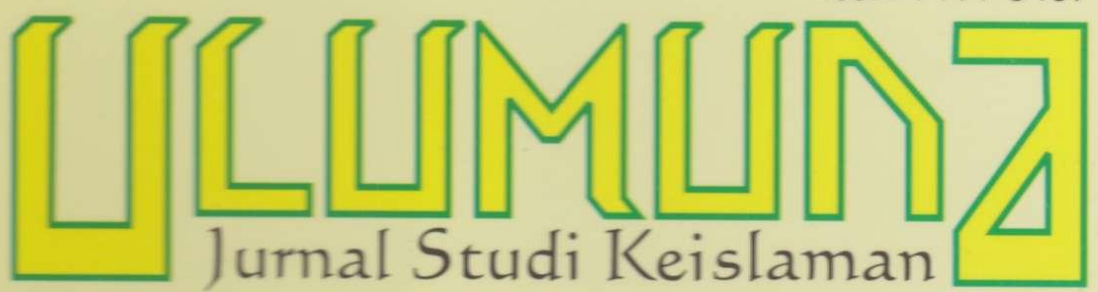

Volume 16 • Nomor 2• Desember 2012

Terakreditası B; SK Dirjen Dikti Kemdikbud Nomor: 56/DIKTI/Kep/2012, Tanggal 24 Juli 2012

REORIENTASI KAJIAN TEOLOGI ISLAM: IKHTIAR KONTRIBUTIF ATASI PROBLEM KEKINIAN Muhammad Rusli

PERGOLAKAN TEOLOGI SYIAH-SUNNI: MEMBEDAH POTENSI INTEGRASI DAN DISINTEGRASI

Slamet Mulyono MEnimbang KontorVERSI PEMAKNAAN KONSEP AHL AL-KITĀB DALAM AL-QUR'AN Zulyadain ECOTHEOLOGY:

TEOLOGI KONSTRUKTIF ATASI KRISIS LINGKUNGAN Abdul Quddus AKU DALAM TUHAN: IMPLIKASI TEOLOGI PROSES PADA ERA KONTEMPORER Suhermanto la'far PERgulatan TEOLOGI SALAFI DALAM MAINSTREAM KEBERAGAMAAN MASYARAKAT SASAK Faizah STUDI KOMPARATIF KONSEP KETUHANAN ISLAM DAN AGAMA ADAM PADA KOMUNITAS SAMIN Mohammad Rosyid KEGALAUAN IDENTITAS:

Dilema Hubungan Komunitas Muslim dan Hindu di BalI Siti Raudhatul Jannah 



\section{DAFTAR ISI}

\section{Pedoman Transliterasi}

223-244 • Muhammad Rusli,

"Reorientasi Kajian Teologi Islam:

Ikhtiar Kontributif Atasi Problem Kekinian"

245-278 • Slamet Mulyono,

"Pergolakan Teologi Syiah-Sunni:

Membedah Potensi Integrasi dan Disintegrasi"

279-310 Zulyadain,

"Menimbang Kontorversi Pemaknaan

Konsep Ahl Al-Kitāb Dalam Al-Qur'an"

311-346 • Abdul Quddus,

"Ecotheology:

Teologi Konstruktif Atasi Krisis Lingkungan"

347-374 • Suhermanto Ja'far,

"Aku dalam Tuhan:

Implikasi Teologi Proses pada Era Kontemporer"

375-402 • Faizah,

"Pergulatan Teologi Salafi

dalam Mainstream Keberagamaan Masyarakat Sasak"

403-442 • Mohammad Rosyid,

"Studi Komparatif Konsep Ketuhanan Islam

dan Agama Adam pada Komunitas Samin"

443-464 • Siti Raudhatul Jannah,

"Kegalauan Identitas: Dilema Hubungan

Komunitas Muslim dan Hindu di Bali"

\section{INDEKS}

APENDIKS 


\section{PEDOMAN TRANSLITERASI}

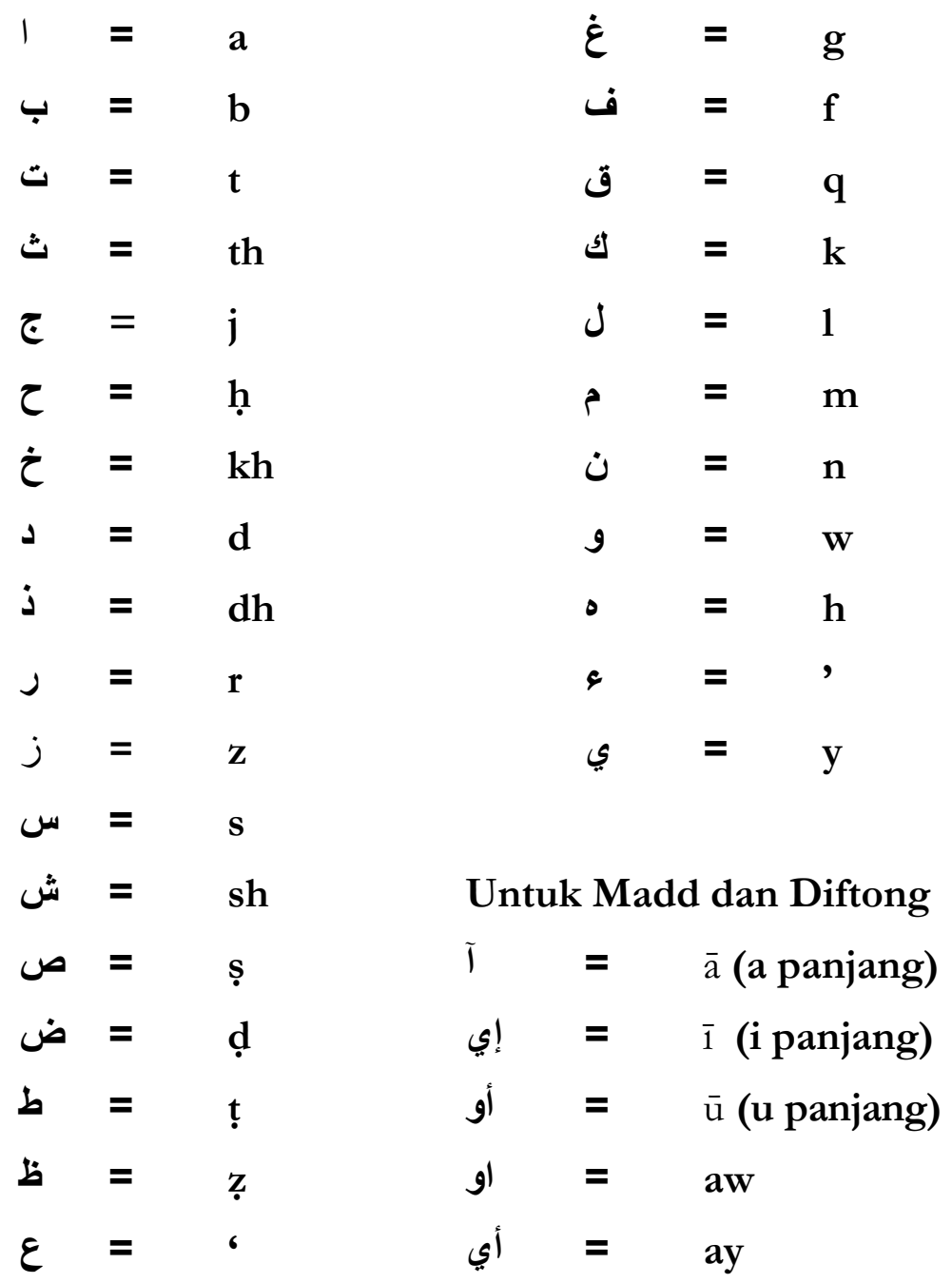

Contoh penulisan dengan transliterasi:

اعوذ بالله من الشيطان الرجيم (a'üdhu bi al-Lāh min al-shaytān al-rajim);

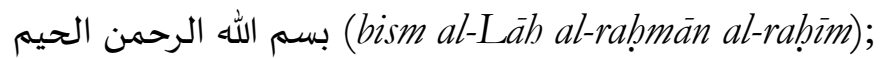

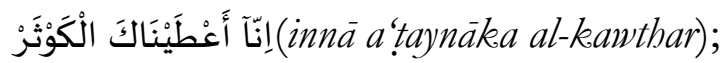

فَصَلِّ لِرَبِكَ وَانْحَرْ (fasalli lirabbika wanhar); صباح الخير (sabāh al-khayr). 


\title{
PERGULATAN TEOLOGI SALAFI \\ DALAM MAINSTREAM KEBERAGAMAAN \\ MASYARAKAT SASAK
}

\author{
Faizah
}

(Fakultas Dakwah IAIN Mataram

Email: faizbundayada@gmail.com)

Abstract: The Salafi movement has recently spread so widely in Indonesia that it has reached rural communities. In that context, its contact with local beliefs and practices produces a dynamic and creative tension between them. This paper will explore the contact dynamics by photographing wrestle of Salafi's theological movement and beliefs in the mainstream of theological beliefs of local Sasak society of Lombok. The authors found that local knowledge that expressed through practicing several ceremonies associated with the buman life-cycle from moment of human birth to death events considered by the Salafi as unauthentic element of Islam called heretic to which the Salafi has to carry out purification. That potential conflict between the Sasak and Salafis, requiring mutual respect and tolerance among them.

Abstrak: Gerakan Salafi akbir-akbir ini semakin meluas penyebarannya di Indonesia bingga mencapai wilayah-wilayah pedesaan. Dalam konteks itu persentuhannya dengan keyakinan dan praktek masyarakat lokal menciptakan dinamika dan ketegangan kreatif di antara mereka. Tulisan ini akan mengupas dinamika itu dengan memotret pergulatan pabam teologi gerakan Salafi itu di tengah mainstream keyakinan keberagamaan masyarakat Sasak, Lombok. Penulis menemukan babwa keyakinan lokal yang diekspresikan melalui penyelenggaraan beberapa upacara yang berhubungan dengan lingkaran bidup manusia dari peristiwa kelabiran bingga kematian dipandang oleh kaum Salafi sebagai unsur baru yang disebut bid'ah dan keharusan bagi Salafi untuk melakukan purifikasi. Hal itu berpotensi menimbulkan konflik antara Sasak dan Salafi, sehingga diperlukan sikap saling menghargai dan tenggang rasa di antara mereka.

Keywords: teologi Salafi, bid'ah, Wahabiah, wabyu, akal, worldview, tawbid radikal, fundamentalis, literalis. 
ISTILAH Salafi merupakan terminologi baru yang sulit dideteksi dan diketahui kapan penggunaannya mulai tersebar. Salafi bukanlah sebuah mazhab, sebagaimana misalnya mazhab Maliki atau Syafi'i, bukan pula kelompok yang terorganisir seperti Ikhwanul Muslimin. Gerakan Salafi lebih sebagai semangat yang menyebar di dunia Islam semenjak masa tabi'in dan terkenal dengan sebutan al-salaf atau Abl al-Atsar yang dikontradiksikan dengan Abl al-Ra'yi. ${ }^{1}$ Istilah Salafiyyah biasanya diidentikkan dengan Abl al-Hadits atau para pengikut Imam Ahmad bin Hanbal yang mewarisi aliran $A b l$ al-Hadits sebagai lawan dari $A b l$ al-Kalām dalam akidah serta $A b l$ al-Ra'yi dalam ilmu fikih.

Salaf sendiri berarti pendahulu, dan dalam konteks Islam, pendahulu itu merujuk kepada periode Nabi, para sahabat, dan tabi’in. Selain itu, istilah salafi mempunyai makna fleksibel dan lentur serta memiliki daya tarik natural, sebab ia melambangkan autentisitas dan keabsahan. Sebagai suatu istilah, kata salafi dimanfaatkan oleh setiap orang dan gerakan yang ingin mengklaim dirinya bahwa gerakan tersebut berakar pada autentisitas Islam. Walaupun istilah ini pada awalnya dipakai oleh kaum reformis liberal, namun pada awal abad XX $M$, kaum Wahabi juga menyebut diri mereka sebagai kelompok Salafi. ${ }^{2}$ Term salaf digunakan juga untuk menyebut para ulama $A b l$ alSunnah wa al-Jama'ah sesudah tiga generasi yang diberkahi yang mengikuti jalan mereka dalam keyakinan dan perilaku. Menurut kelompok Salafi, di antara para ulama tersebut adalah Abū Hanīfaț, al-'Awzā̄̄ō, al-Layts bin Sa’ad, Imām Mālik bin Anas, 'Abdullāh bin al-Mubārak, Shafyān bin al-'Uyainat, Imām alSyāfi'i, Imām Ishāq, Aḥmad bi Hanbal, Imām al-Bukhārī, Imām al-Muslim, Abū Dāud, Ibn Taymiah, Ibn Qayyim al-Jawzī, Ibn Katsīr, Muhammad bin 'Abd al-Wahhāb dan sejumlah muridnya seperti 'Abd al-'Azīz bin Bazz dan Nashīr al-Dīn al-Albān̄i. ${ }^{3}$

${ }^{1}$ Aḥmad Farīd dan Sāleh al-Fawzān, al-Salafiyyat Qawāid wa al-Ushül; Ta'qibat 'alā Kitāb al-Salafiyyat Laisat Mą̧haban, ter. Muhammad Muhtadi, Polemik Salafi (Solo: Multazam, 2009), 21.

${ }^{2}$ Khaled Abou El Fadl, The Great Theft: Wrestling Islam from the Ekstrimists, ter. Helmi Musthafa, Selamatkan Islam dari Muslim Puritan (Jakarta: PT. Serambi Ilmu Semesta, 2005), 107.

${ }^{3}$ M. Imdadun Rahmat, Arus Baru Islam Radikal: Transmisi Revivalisme Islam Timur Tengah ke Indonesia (Jakarta: Penerbit Erlangga, 2005), 64. 
Bagi masyarakat Sasak, ${ }^{4}$ Salafi adalah sebuah kelompok atau aliran keagamaan yang memiliki pengamalan keagamaan yang berbeda dengan mereka. ${ }^{5}$ Masuknya paham Salafi yang secara kontinyu melalui pengajian, mengecam praktek-praktek agama dan kultural yang secara nyata dilakukan oleh masyarakat Sasak merefleksikan usaha kelompok Salafi untuk melakukan purifikasi, karena mereka menganggap pengamalan keagamaan masyarakat Sasak banyak diwarnai bid'ah. Di sisi lain, kelompok Salafi berhadapan dengan budaya masyarakat Sasak yang mengutamakan komunitas dan solidaritas sosial. 6 Sedangkan masyarakat Sasak menganggap bahwa sebuah kultur lokal dapat diterima sejauh tidak bercampur dengan ibadah Islam dan bertentangan dengan ajaran-ajaran Islam yang mendasar. ${ }^{7}$

Ada beberapa aspek dari ajaran-ajaran dan praktek-praktek Salafi yang membedakannya dengan masyarakat Islam lainnya. Perbedaan ini terutama berkaitan dengan perbedaan-perbedaan pandangan mengenai karakteristik dan kemampuan individu menjalankan kewajiban agama, hubungan antara kultur lokal dan Islam, serta orientasi teologis mereka terhadap dua spirit, dunia dan akhirat. Perbedaan-perbedaan ini kadang-kadang tidak

${ }^{4}$ Sasak merupakan suku asli yang menempati pulau Lombok. Lombok sendiri merupakan tempat bertemunya tiga kebudayan besar Nusantara yaitu kebudayaan Jawa Kuno (Hindu Majapahit), Islam, dan Hindu (Hindu Bali). Karena itu, di daerah ini berkembang suatu adat istiadat yang merupakan akulturasi dari ketiga kebudayaan di atas. Di antara beberapa kebudayaan yang pernah berkembang di Lombok, Pengaruh orang-orang Hindu pada kepercayaan dan praktek-praktek Islam, mungkin yang paling signifikan, meskipun seberapa luasnya pengaruh tersebut sangat sulit untuk ditentukan secara pasti. Namun terdapat contoh dari pengaruh orang-orang Hindu yang paling mungkin dapat dilihat dalam sinkertis Wetu Telu yang praktek-praktek dan sistem kulturalnya, nampak menyerupai praktek-praktek dan kosmologi orang-orang Bali (Hindu) dalam beberapa hal. Lihat, Ahmad Amin, et.al., Adat Istiadat Daerah Nusa Tenggara Barat (NTB) (Jakarta: Departemen Pendidikan dan Kebudayaan RI, 1997), 115-9.

${ }^{5}$ Lihat Lombok Post, 25 November 2005.

'Dalam berbagai ritual keagamaan atau adat, masyarakat Sasak sangat menekankan pentingnya arti kebersamaan. Dalam hal ini terlihat dari tradisi dan budaya rowah, begibung, nyongkolan yang melibatkan komunitas masyarakat dalam jumlah yang besar. Jika seseorang tidak melibatkan diri dalam prosesiprosesi ini akan mendapatkan sanksi sosial.

7TTabloid, Perspektif, edisi, 1 s/d 31 Maret 2009. 
kentara dan kadang-kadang juga sangat kentara, dan mereka biasanya memperdebatkannya dalam pengertian yang dianggap sebagai Islam yang benar dan yang tidak benar. ${ }^{8}$

Latar belakang suku Sasak yang sangat kental dengan budaya dan adat membentuk tradisi keagamaan yang banyak diwarnai oleh akulturasi budaya dan agama. ${ }^{9}$ Maka tidak mengherankan jika kedatangan kelompok Salafi juga dianggap sebagai ancaman terhadap paham keagamaan yang telah menyatu dengan budaya lokal.

\section{Salafi dalam Lintasan Sejarah}

Gerakan Salafi pada awalnya muncul sekitar abad ke-IV H, yang dipelopori oleh ulama-ulama dari mazhab Hambali yang ingin menghidupkan kembali tradisi-tradisi ulama-ulama terdahulu (salaf al-shälib). ${ }^{10}$ Kemunculan gerakan ini sangat terkait

8Jamhari dan Jajang Jahroni (ed.), Gerakan Salafi Radikal di Indonesia (Jakarta: PT. Raja Grafindo Persada, 2004), VII.

'Setidaknya terdapat dua varian Islam yang berkembang di kalangan masyarakat Lombok, yaitu komunitas Wetu Telu dan komunitas yang dikenal dengan Waktu Lima. Komunitas Wetu Telu adalah orang Sasak yang meskipun mengaku sebagai muslim, namun masih sangat percaya terhadap ketuhanan animistik leluhur maupun benda-benda antromorfis. Sebaliknya Waktu Lima adalah orang-orang muslim Sasak yang mengikuti ajaran atau syari'at secara lebih utuh dan konsisten sebagaimana diajarkan dalam pemahaman Islam ortodoks. Lihat, Erni Budiwanti, Islam Sasak Wetu Telu Versus Waktu Lima (Yogyakarta: LKiS, 2000), 6-8.

${ }^{10}$ Sukar untuk mengetahui sejak kapan istilah salaf mulai dipakai. Orangorang yang dapat dikatagorikan sebagai ulama Salaf tidak lebih dari orangorang yang hidup dalam jangka tiga ratus tahun, terhitung sejak masa Nabi. Pikiran ini didasarkan pada sebuah hadis yang terdapat dalam Shahịh Bukhäri dan Muslim yang berbunyi, "Sebaik-baik kaum adalah kurunku, kemudian yang berikutnya, kemudian yang berikutnya lagi". Jadi, dengan hadis ini Rasulullah menerangkan bahwa orang-orang muslim yang terbaik adalah mereka yang hidup dalam masanya (sahäbat), kemudian orang-orang yang sesudah masa itu (täbi'ìn), kemudian yang sesudahnya (atbä' al-täbi'inn). Yang dimaksud dengan kurun adalah suatu masa yang lamanya seratus tahun. Dengan demikian, para ulama membagi pengikut Islam menjadi tiga masa, masa sahabat, täbi'in dan atbä' al-täbi'in. Ulama yang menetapkan satu kurun itu adalah seratus tahun mendasarkannya kepada sebuah hadis bahwa Rasulullah pernah pada suatu hari mengusap kepala seorang anak yatim seraya berkata, "Moga-moga hiduplah engkau selama satu kurun". Menurut 
dengan permasalahan teologis, yaitu peristiwa inkuisasi al-Qur'an dan terjadinya pengekangan dan intimidasi terhadap Imām Aḥmad bin Hanbal (w. $241 \mathrm{H} / 855$ M) oleh penguasa Abbasiyyah yang menganut paham Mu'tazilah. ${ }^{11}$

Kemudian, sekitar akhir abad ke-VII H, gerakan ini dihidupkan kembali oleh Ibn Taymiah (w. 729 H/1329 M) sebagai respons terhadap berkembangnya paham-paham rasional di kalangan umat Islam dan munculnya kecenderungan umat Islam terhadap filsafat dan ilmu kalam yang dianggap telah menyimpang dari al-Qur'an dan Hadis serta tradisi-tradisi ulamaulama salaf. ${ }^{12}$ Pada pertengahan abad ke-XII H atau akhir abad ke-XVII M, paham Salafi mengkristal dalam sebuah gerakan yang dinamakan Wahabiyyah yang dinisbahkan kepada pelopornya yaitu Muḥammad bin 'Abd al-Wahhāb (w. 1201 $\mathrm{H} / 1787 \mathrm{M}) .{ }^{13}$

Kemunculan kembali gerakan Salafi melalui tangan Muhammad bin Abdul Wahhab menambahkan kepada gerakan ini karakter khusus yaitu memerangi segala bentuk kemusyrikan dan khurafat, menyerukan kemurnian tauhid serta melindungi ketauhidan dari segala penyimpangannya. ${ }^{14}$ Ia berusaha

penyelidikan, benarlah anak yatim yang pernah diusap kepalanya dan didoakan Nabi hidup seratus tahun lamanya. Lihat, Aboebakar Atjeh, Salaf (Salaf al-Sälih) Islam dalam Masa Murni (Jakarta: Permata, 1970), 5-6. Lihat juga, 'Abd al-Halīm al-Jundī, Muhammad bin 'Abd al-Wahbāb aw Intishār Mazhab al-Salafì (Kairo: Dār al-Ma’ārif, 1986), 27.

11Lihat: 'Alī Sāmī al-Nasyār, Nasy'at al-Fiker al-Falsafi fì al-Islām (Kairo: Dār al-Ma'ārif, 1981), cet. III, jilid I, 257.

${ }^{12}$ Dalam berbagai karyanya Ibn Taymiah banyak mengkritik pendapatpendapat para filosof dan Mutakallimin (teolog) terutama dalam permasalahan-permasalahan yang terkait dengan permasalahan epistemologi dan metafisika. Lihat misalkan kritik Ibn Taymiah terhadap logika Aristoteles dalam karyanya al-Radd 'alà Mantiq Aristhū (Kritik terhadap Logika Aristoteles), al-Iklīl fi al-Mutasyäbih wa al-Ta'wīl (Essei-essei tentang Antromorfisme dan Takwil), al-'Aqìdah al-Muhammadiyyat al-Kubrā (Akidah Muhammadiyyah) dan lain-lain.

13Lihat: Muhammad Aḥmad Abū Zahraț, al-Mazāhib al-Islämiyyat (Mesir: al-Matba'at al-Namūjaziyat, tt), 311.

${ }^{14 ‘}$ Abd al-Wahhāb, Kitāb, 6-7. Lihat juga, Lembaga Penelitian dan Pengkajian WAMI, al-Mausü'at al-Muyassart fì al-Adyān wa al-Mazāhib alMu'äshirat, ter. A. Najiuyulloh, Gerakan Keagamaan dan Pemikiran: Akar Ideologis dan Penyebarannya (Jakarta: al-Islahy Press, 1995), 228-9. 
membersihkan Islam dari kerusakan yang dipercayainya telah merasuk dalam Islam. Ia juga menerapkan literalisme yang ketat dan menjadikan teks sebagai satu-satunya sumber otoritas yang sah serta menampilkan permusuhan yang ekstrem kepada intelektualisme, mistisme, dan semua perbedaan sekte yang ada dalam Islam. Ia ingin membebaskan ummat Islam dari keterkungkungan dalam bid'ah zaman kemunduran. ${ }^{15}$

Menurut doktrin Wahabi, penting artinya kembali pada kemurnian, kesederhanaan, dan kelurusan Islam yang sepenuhnya diperoleh dengan cara menaati perintah Nabi secara harfiah dan dengan ketaatan penuh terhadap praktik ritual yang benar. Wahabi menolak semua upaya untuk menafsirkan hukum Allah secara historis dan kontekstual karena dapat menimbulkan multitafsir dan interpretasi seiring dengan perkembangan zaman. Wahabi menganggap sebagian besar sejarah ummat Islam adalah unsur perusak Islam dari kemurniannya. Wahabi juga mendefinisikan ortodoksi secara sempit dan sangat tidak toleran terhadap semua kepercayaan adat (lokal) yang bertentangan dengan kepercayaannya. ${ }^{16}$

Menurut Imarah, ada tiga hal yang sangat mendasar dan menjadi karaktristik gerakan Wahabi. Pertama, menentang dengan keras segala pemikiran yang berbau filsafat, ilmu kalam, dan tasawuf (mistik). Kedua, menentang dengan keras segala keyakinan yang bersifat bid'ah dan khurafat. Ketiga, menentang segala bentuk interpretasi rasional (intelektualitas). ${ }^{17}$

Ironisnya, sebagai sebuah gerakan, Salafisme justeru dimunculkan kembali pada awal abad XX M oleh Jamaluddin alAfghani dan kawan-kawannya yang berorientasi liberal. Kemunculannya sebagai respons terhadap modernitas yang mengajak kaum muslimin untuk kembali kepada sumber murni yaitu al-Qur'an dan hadis. Motor utama gerakan Salafi ini adalah Jamaluddin al-Afghani (w. 1314 H/1897 M), Muhammad Abduh (w. 1323 H/1905 M), Rasyid Ridha (w. 1354 H/1935 M) dan Muhammad Syawkani (w. 1250 H/1834 M). Untuk

${ }^{15}$ Rahmat, Arus, 71.

16Ibid., 66-7.

${ }^{17}$ Muḥammad Imārah, Thayyārat al-Fiker al-Islām (Kairo: Dār al-Syurūq, 1995), 254. 
merespons modernisasi, menurut Jamaluddin al-Afghani, Muhammad Abduh, dan Rasyid Ridha, kaum muslimin harus kembali pada ajaran Islam, yaitu al-Qur'an dan sunnah serta mengkaitkan diri dengan penafsiran teks. Muhammad Rasyid Ridha, pendiri majalah al-Manār, penulis Tafsìr al-Manār, serta berbagai buku reformasi Islam lainnya menjadi penggerak utama gerakan Salafi yang banyak diwarnai oleh gurunya, Muhammad Abduh yang sangat terbuka dengan pemikiran Barat. Akibatnya, dia tidak terlalu dilirik oleh kalangan Salafi modern. Mereka tidak memanfaatkan aliran pembaharuan Rasyid Ridha sebagaimana mestinya. Padahal, ia adalah pemimpin sejati dari gerakan Salafi yang tercerahkan. ${ }^{18}$ Karya-karya yang lahir dari tokoh seperti Muhammad Abduh dan Rasyid Ridha, yang memperlihatkan tingkat kecanggihan intelektual menjadi jarang ditemukan. Teksteks yang ditulis oleh kaum Salafi kemudian menjadi tidak bisa dibedakan dari tulisan kaum Wahabi. Perpaduan Salafisme dan Wahabisme ini menurut Khaled Abu El-Fadl telah mulai terjalin pada era 1970-an yang membentuk gerakan yang dalam istilah para penulis kontemporer sebagai pembentukan teologi gerakan Islam puritan. ${ }^{19}$

Gerakan Salafi yang pada awalnya memfokuskan diri pada permasalahan-permasalahan akidah (teologi), pada abad-abad belakangan seperti yang dikatakan oleh Ibrahim Madkur mengalami pergeseran dengan memfokuskan diri pada permasalahan-permasalahan ibadah (furü'iyyat) dengan mengajak menghidupkan sunnah-sunnah Nabi, seperti menetapkan bahwa merokok hukumnya haram, memotong jenggot hukumnya makruh, merayakan peringatan maulid Nabi, pembacaan talkin bagi yang telah meninggal, melakukan zikir jahr setelah shalat, perayaan dan doa nishf Sya'bān (doa pertengahan bulan Sya'ban) hukumnya bid'ah serta menganjurkan membongkar bangunan di atas kuburan dan lain-lain. ${ }^{20}$

${ }^{18 Y u s u f}$ Qardhawi, Kebangkitan Gerakan Islam: Dari Transisi Menuju Kematangan, ter. Abdullah Hakam Syah dan Ainul Abied Syah (Jakarta: Pustaka Al-Kautsar, 2003), 236.

${ }^{19} \mathrm{Abu}$ El-Fadl The Great, 95.

${ }^{20}$ Ibrāhīm Madkūr, Fì al-Falsafat al-Islämiyyat Manhajubu wa Thatbiqubu (Kairo: Dār al-Ma'ārif, tt), jilid II, 44. 
Di Indonesia, ide-ide gerakan pemikiran Salafi berkembang sejak era Kolonial Belanda. Salah satu gerakan pemikiran Salafi awal di Indonesia terdapat di Minangkabau. Gerakan ini dipelopori oleh Tuanku Nan Tuo, tokoh kaum Paderi dari Koto Tuo Ampek Angkek Candung (1784-1803). Dari nama kaum inilah maka pertempuran antara kaum Paderi melawan Belanda dinamakan dengan perang Paderi. Sumber kepustakaan menjelaskan bahwa gerakan Paderi ini dipengaruhi oleh gerakan keagamaan Wahabi (1703-1792) yang sangat mempengaruhi para jama'ah haji dari ranah Minang yang belajar ke Makkah. ${ }^{21}$

Gerakan pemikiran Salafi di Indonesia mengalami perkembangan bersamaan dengan munculnya tokoh-tokoh gerakan pemikiran Salafi di Timur Tengah (Mesir) seperti Syeikh Jamaluddin al-Afghani (1839-1897), Muhammad Abduh (18491905), dan Rasyid Ridha (1865-1935). Para tokoh pembaharuan Mesir ini di samping mengajak ummat Islam untuk "kembali kepada al-Qur'an dan sunnah Nabi Muhammad saw.", juga mengajak ummat Islam agar meningkatkan ilmu pengetahuan dan teknologi modern untuk mencapai kemajuan, menghilangkan kebodohan, dan mengatasi keterbelakangan. Orang-orang Indonesia yang menunaikan ibadah haji ke Makkah kemudian bermukim di sana memanfaatkan waktunya untuk belajar agama Islam. Setelah pulang secara individu atau melalui organisasi, mereka melakukan gerakan pembaharuan Islam beraliran Salafi. ${ }^{22}$ Upaya-upaya yang dilakukan oleh para tokoh gerakan keagamaan tersebut adalah mengajak ummat Islam meninggalkan praktek-praktek keagamaan yang bernuansa bid'ah, khurafat, taklid, dan mendorong mereka melakukan ijtibad. ${ }^{23}$ Organisasi-organisasi Islam di Indonesia yang bercorak Salafi modern di antaranya Muhammadiyah (1912), Sarikat Islam (1912), Al-Irsyad (1914), Jong Islamiten Bond (1925-1942), Persatuan Islam (1923), dan Partai Islam Indonesia (1938).

Di Indonesia dan di Lombok hingga saat ini terdapat dua arus gerakan Salafi-Wahabi terkemuka yaitu gerakan Salafi yang

${ }^{21}$ Imam Tholkhah, Gerakan Islam Salafiyah di Indonesia, Jurnal Edukasi, Volume 1, Nomor 3, Juli-September 2003, 35.

${ }^{22}$ Ibid.

${ }^{23}$ Ibid., 36. 
berpatron kepada Arab Saudi dengan imamnya Ja'far Umar Thalib dan gerakan Salafi yang berkiblat ke Kuwait dengan pimpinannya Abu Nida, Abu Hakim, Yusuf Baisa, dan Yazid bin Abdul Qadir Jawaz. ${ }^{24}$

\section{Teologi Salafi}

\section{Konsep tentang Tuban (Taubid), Alam, dan Manusia}

Konsep tauhid merupakan konsep sentral pandangan keduniaan (word view) dalam Islam. ${ }^{25}$ Secara etimologis, kata tawhid merupakan bentuk masdar dari kata kerja lampau (fi'l almädhi) waḥhada yang merupakan turunan dari akar kata wahdah yang berarti keesaan, kesatuan, dan persatuan. Secara istilah, tawhid berarti menyakini bahwa Allah adalah Esa dan tidak ada sekutu bagi-Nya.

Dalam Islam, Tuhan adalah suatu Zat yang Maha segalanya, sempurna dengan segenap kemuliaan-Nya serta terhindar dari berbagai kekurangan. ${ }^{26}$ Tidak ada perbedaan pendapat di kalangan ummat Islam bahwa Tuhan itu kekal, Dia selalu hadir kapan dan di mana pun, tidak terbagi dan abadi. ${ }^{27}$ Meyakini keesaan Tuhan, keparipurnaan, dan kesempurnaan-Nya sangatlah sentral dalam keyakinan ummat Islam. Tuhan tidak punya sekutu, teman atau yang menyerupai-Nya, dan Dia tidak diperanakkan maupun memperanakkan. ${ }^{28}$

${ }^{24}$ M. Zaki Mubarak, Geneologi Islam Radikal di Indonesia: Gerakan, Pemikiran dan Prospek Demokrasi...,119.

${ }^{25}$ Ismail R. al-Faruqi dan Lois Lamya al-Faruqi, Atlas Budaya Islam (Bandung: Penerbit Mizan, 2000), 176. Isma'il R. al-Faruqi, Tawbid (Bandung: Penerbit Pustaka, 1988), 66. Murtadha Muttahari, Pandangan Dunia Tawhid (Bandung: Penerbit Mizan, 1985), 19.

${ }^{26}$ Buletin al-I'tisham, Nikmat Islam, edisi 18 Shafar $1431 \mathrm{H}$.

${ }^{27}$ Muḥammad bin Shālih al-'Utsaymin, Faṭ̣ Rabb al-Bariyyat bi Talkhish al-Hamawiyyat, ter. Hammad bin 'Amir Abu Mu'awiyah, Aqidah Muslim dalam Tinjauan al-Qur'an dan al-Sunnab (Bekasi: Maktabah Dar el Salam, 2009), 3. Lihat juga, Ibrāhīm Muhammad bin 'Abdullāh al-Buraykan, al-Madkhal li Dirāsat al-'Aqìdat al-Islämiyyat 'alā Madzhab Abl al-Sunnat wa al-Jamä'at, ter. Muhammad Anis Matta, Pengantar Studi Aqidah Islam (Jakarta: Rabbani Press, 1998), 141.

${ }^{28}$ Inilah konsep yang menjadi dasar ajaran-ajaran agama samāwì yang mereka sebut sebagai konsep tauhid. Konsep tauhid adalah konsep yang dibawa oleh para nabi. Lebih lanjut lihat, 'Alī Sāmī al-Nasyār, Nasy'at al-Fiker 
Secara umum, umat Islam mengaplikasikan tauhid ke dalam tiga bagian yaitu tawhid rububiyah, tawhid ulubiyah dan tawhid asma wa shifat. ${ }^{29}$ Tauhid rububiyah berasal dari salah satu nama dan sifat Allah "Rabb" yang artinya "Pemelihara", "Penolong", "Pemilik", "Yang memperbaiki", "Tuan" dan "Wali". Secara istilah, tauhid rububiyah berarti keyakinan bahwa hanya Allah-lah satu-satunya yang menciptakan, mengendalikan, dan memiliki alam semesta ini. Dia-lah yang berkuasa, menghidupkan, memelihara, dan mematikan. ${ }^{30}$

Tauhid ulubiyah diambil dari akar kata iläh yang berarti yang disembah atau ditaati. Secara istilah tauhid ulubiyah berarti mengesakan Allah dalam ibadah dan ketaatan. Artinya, ketaatan seorang muslim dan segala ibadahnya harus diarahkan, ditujukan atau dipersembahkan hanya kepada Allah Swt. Implikasi lainnya bahwa cara-cara beribadah seorang muslim harus sesuai dengan yang ditetapkan Allah dalam al-Qur'an dan yang telah dicontohkan rasul-Nya Muhammad Saw., karena penekanan dan spesifikasi tauhid yang khusus terhadap ibadah, maka tauhid ini disebut juga dengan istilah tawhid ubudiyah. Beberapa dalil tentang tauhid ulubiyah ini di antaranya terdapat dalam Qs. al-Anbiya' (21): 25, yang menyatakan: "Dan Kami tidak mengutus seorang rasulpun sebelum kamu, melainkan Kami wahyukan kepadanya bahwasannya tidak ada Tuban melainkan Aku, maka sembahlah olehmu sekalian akan Aku". Hal ini diperkuat juga dengan beberapa hadis Nabi di antaranya, "Dan hake. Allah atas hamba-hamba adalab hendaknya mereka menyembah-Nya dan tidak mempersekutukan-Nya dengan sesuatu yang lain". ${ }^{31}$

Sedangkan tauhid asma' wa shifat adalah keyakinan yang benar tentang nama-nama-Nya dan kepercayaan sepenuhnya terhadap segala sifat-sifat-Nya, dan bahwa nama-nama-Nya adalah sifatNya seperti yang tercantum dalam teks-teks agama. Para ulama

al-Falsafì fì al-Islām (Kairo: Dār al-Ma'ārif, cet. II, tt), 29-30. Lihat juga, M. Quraish Sihab, Wawasan al-Qur'an (Bandung: Penerbit Mizan, 2000), 18-21.

${ }^{29}$ Lihat: Imām al-Ghazālī, al-Iqtishāed fì al-I'tiqād (Mesir: Maktabaṭ Muhammad Subayh, 1962), 198. Bandingkan dengan, Yazid bin Abdul Qadir Jawaz, Syarh Aqidah Ablussunnah wal Jama'ah (Bogor: Pustaka Imam alSyafi'i, 2004), 146-162.

${ }^{30}$ Qs. al-Baqaraṭ (2): 29, Qs. al-A'rāf (7): 53, dan Qs. Yūnus (10): 31-32.

${ }^{31}$ Imām al-Bukhārī, Shahīh al-Bukhārì, Kitāb Libās 151, vol. 7, 64. 
sepakat bahwa seorang muslim harus mengakui dan meyakini bahwa semua nama dan sifat Allah Swt. yang termaktub dalam al-Qur'an dan hadis itu berbeda dengan siapapun dan apapun juga berdasarkan firman Allah dalam Qs. asy-Syūrā (26): 11, dan Qs. al-Ikhlās (112): 4.

Timbulnya perbedaan interpretasi antara para mutakallimin atau teolog hanya berkaitan dengan sifat-sifat kbabariyat (sifat antroformis) yang terdapat dalam berbagai surah dalam alQur'an seperti yadullāh (tangan Allah) dalam Qs. Āli 'Imrān (3): 73, qabdhatubu (genggaman-Nya) dalam Qs. al-Zumar (39): 67, bi a'yuninā (dengan mata-mata Kami), wajhu rabbika (wajah Tuhan) dalam Qs. al-Raḥmān (55): 27, serta istawā 'alā al-'arsy (Dia bersemayam di atas 'Arsy) dalam Qs. Tāhā (20): 5.

Dalam memahami ayat-ayat tersebut, para ulama terbagi ke dalam tiga kelompok. Pertama, kelompok yang mengartikannya secara harfiyah atau literalis. Kedua, kelompok yang menganggap ayat tersebut bersifat metaforis (kiasan), sehingga ayat-ayat tersebut harus ditafsirkan secara majazi, misalnya tangan Allah (yadullāh) diartikan dengan kekuasaan Allah, mata Kami (a'yunina a) diartikan dengan pengawasan Tuhan, wajah Tuhanmu (wajh rabbika) menjadi diri atau zat Tuhan, istawà 'alà al-arsy dengan berkuasa dalam kekuasaan-Nya. Ketiga, kelompok yang mengambil sikap pertengahan yaitu mereka yang membenarkan kalau Tuhan itu memang memiliki mata, tangan dan wajah, namun bagaimana persisnya mata, tangan dan wajah Tuhan manusia dengan akalnya tidak akan mengetahuinya dan tidak mungkin mampu mendefinisikannya. ${ }^{32}$

Kelompok Salafi lebih memahami ayat-ayat tersebut secara tekstual apa adanya dan manusia tidak dituntut untuk mengetahui dan mendefinisikannya. Hal ini mereka sandarkan pada pendapat Imām Mālik yang menyatakan, "Duduk di singgasana adalah sesuatu yang diketabui, sedangkan bagaimana dudukNya Tuban tidak dapat diketabui dan bertanya tentang-Nya adalah bid'ab". 33

${ }^{32} \mathrm{Abū}$ al-Hasan ibn Ismā'il al-Asy'arī, al-Ibānat fì Ushūl al-Diyānat, (Hyderabad: tp. tt.), 47.

${ }^{33}$ Muḥammad bin Shalīh al-Usaymin, Fath Robbi al-Bariyyat bi al-Talkhis al-Hamawiyyat, ter. Hammad bin 'Amir Abu Mu'awiyyah, Aqidab Muslim 
Bagi Salafi, akidah Islam mesti dikembalikan kepada asalnya yang murni, dan menekankan pada pemurnian arti tauhid dari syirik dengan segala menifestasinya. Pemurnian tauhid ini dimaksudkan dengan menuntut kepada ummat Islam agar mengembalikan tauhid kepada apa yang dipahami ummat Islam pada masa awal Islam. ${ }^{34}$ Akidah para sahabat dalam hal ini adalah tolak ukur yang benar, akidah mana pun yang menyelisihi akidah para salaf, maka itu adalah akidah batil. Karena kebenaran (al-haq) itu adalah apa yang diwariskan oleh Nabi dan para salaf al-shälih.

Pemahaman tentang tauhid kelompok Salafi menekankan bahwa alam pada hakekatnya adalah milik Allah dan akan kembali kepada-Nya. ${ }^{35}$ Dalam konsep Islam, alam tidak diciptakan secara sia-sia. Di dalam penciptaan alam dan manusia terdapat tujuan-tujuan yang bijaksana. Segala sesuatu diciptakan mengandung kebijaksanaan dan hikmah. Tatanan yang ada adalah tatanan yang terbaik dan sempurna. Di alam ini, kehendak Allah berjalan dalam bentuk norma (sunnah), yakni dalam bentuk hukum alam dan prinsip-prinsip yang tidak berubah. ${ }^{36}$ Bagi manusia, baik dan buruk peruntungan di akhirat bergantung pada bentuk perilaku di dunia ini, yakni bagaimana ia menghadapi alam dan bagaimana ia berbuat. Baik dan buruk perbuatan, di samping bahwa keduanya mendatangkan pahala dan siksaan di akherat juga menimbulkan reaksi-reaksi di dunia ini. 37

Dengan menggunakan terminologi keagamaan, Islam menyatakan bahwa manusia diciptakan untuk mengabdi kepada Tuhan. Tuhan berfirman dalam Qs. al-Dhāriyāt (51): 10, "Dan tiadalah Aku ciptakan jin dan manusia kecuali untuk beribadah kepada$K u$ ". Jelas dikemukakan tentang tujuan hidup manusia, yang juga

dalam Tinjauan al-Qur'an dan as-Sunnah (Bekasi: Maktabat Dar al-Salam, 2009), 12.

${ }^{34} \mathrm{WAMI}$, al-Mausü'at, 230.

35'Abd al-Mālik bin Ahmmad Ramdhān̄̄, Sittu Durar min Ushūl Abl alAtsar, ter. Mubarak Bamu'allim, Enam Pilar Dakwah Salafiyyah (Surabaya: Pustaka Imam al-Syafi'i, 2005), 33.

${ }^{36}$ Muhammad 'Imaduddin 'Abdulrahim, Islam Sistem Nilai Terpadu (Jakarta: Gema Insani, 2002), 19.

${ }^{37}$ Muthahhari, Pandangan, 19. 
merupakan tujuan semua ciptaan. ${ }^{38}$ Al-Qur'an menekankan bahwa manusia harus pasrah pada Tuhan dan mengikuti perintah-perintah-Nya dan al-Qur'an mengingatkan manusia agar tidak menundukkan Tuhan di bawah pengaruh hawa nafsu mereka sendiri. Jelas bahwa di dalam hubungan ini, Tuhan adalah yang paling Unggul dan Tertinggi dan manusia harus mendekati Tuhan dengan ketundukan, rendah hati, dan penuh rasa syukur.

Kalangan Salafi menggambarkan pola hubungan antara Tuhan dan manusia dengan cukup sederhana dan mudah dipahami. Yazid bin Abdul Qadir Jawas, seorang tokoh Salafi, menyatakan bahwa manusia diciptakan untuk tunduk pada Tuhan melalui ritual ibadah. Praktek ritual merupakan bukti yang menunjukkan ketundukan total kepada Tuhan dan dengan begitu, mereka menganggap bahwa kesempurnaan praktek ritual adalah tujuan tertinggi, karena ketundukan kepada Tuhan bergantung pada praktek ritual yang benar, ketundukan tidak dimungkinkan kalau orang tidak menerima Islam. Karena itu, jalan ke arah ketundukan hanya tersedia melalui Islam, karenanya, hanya dengan menjadi muslim seseorang mendapat kesempatan untuk tunduk pada Tuhan. ${ }^{39}$

\section{Peran Wabyu dan Akal}

Tidak ada masalah yang paling membedakan antara Salafi dan kelompok Islam lainnya melebihi topik tentang dasar-dasar teologis dan fungsi hukum. Sebagian kelompok dalam Islam seperti Salafi begitu ketat dalam memahami dasar-dasar teologis dan penerapan hukum, sehingga sebagian orang Barat seperti dikatakan Abou el Fadl sampai berfikir bahwa seorang muslim yang menegaskan syari'at diyakini sebagai seorang yang fanatik atau fundamentalis, sehingga ketika hukum Islam disebut, yang mencuat dalam benak banyak orang Barat adalah kekejaman yang menghebohkan yang dilakukan oleh orang Taliban, Wahabi, dan kaum fundamentalis di Sudan dan yang terakhir

${ }^{38}$ al-Faruqi, Tawhid, 66.

${ }^{39}$ Yazid bin Abdul Qadir Jawas, Syarah Aqidah Ablus Sunnab wal Jama'ah (Bogor: Pustaka Imam Asy-Syafi'i, 2004), 120. 
dengan kemunculan kelompok Islam radikal. ${ }^{40}$ Padahal, untuk menyebut seseorang itu fanatik bergantung pada persepsi yang dimiliki orang tersebut tentang dasar-dasar teologis dan hukum Islam serta interpretasi yang dilakukannya.

Dalam diskursus hukum Islam, selain al-Qur'an dan hadis, ada beberapa sumber yang dipakai para ahli hukum dalam menetapkan putusan-putusan hukum yaitu ijmä' dan qiyās. Para ahli hukum menggali ketentuan hukum dengan menggunakan prinsip analogi (qiyās), mereka memperluas cakupan putusan yang sama dan kasus sebelumnya pada kasus baru karena kasus lama dan baru ini memiliki kesamaan substansi. ${ }^{41}$ Di samping itu digunakan pula prinsip-prinsip keseimbangan (al-qisth), budaya atau tradisi (al-'ádat atau al-'urf), dan kepentingan publik (mashälì al-mursalat) dalam rangka menjadikan hukum bersifat responsif terhadap lingkungan dan kondisi yang berubah. ${ }^{42}$ Dalam hal ini, nampaknya kelompok Salafi terlihat lebih ketat dan tertutup dengan hanya berpijak pada al-Qur'an dan sunnah saja.

Menurut Abou el Fadl, apa yang lazimnya disebut sebagai hukum Islam pada kenyataannya terbagi ke dalam dua kategori yang berbeda syari'at dan fikih. ${ }^{43}$ Syari'at adalah hukum yang abadi, tetap, dan tak berubah sebagaimana ia ada di dalam pikiran tuhan. Sebaliknya, fikih adalah hukum manusia, ia adalah upaya manusia untuk mencapai dan memenuhi hukum abadi sebagaimana yang ada dalam benak tuhan. Artinya, fikih bukanlah tuhan itu sendiri, sebab ia adalah produk usaha manusia. Fikih berbeda dengan syariat, ia tidak abadi, tidak ajeg, atau tidak berubah. Fikih sendiri bersifat manusiawi, dan karena itu mungkin keliru, dapat diubah, dan bersifat kondisional.

${ }^{40} \mathrm{Abu}$ El Fadl, The Great, 173. Mengenai kekerasan yang dilakukan oleh milisi Ikhwan (Wahabi) terhadap ummat Islam lihat lebih lanjut, Stephen Sulaiman Schwartz, The Two Face of Islam: Studi Fundamentalism and Its Role in Terorism, alih bahasa oleh Hodri Ariev, Dua Wajah Islam Modernisme Vs Fundamentalisme dalam Wacana Global (Jakarta: Penerbit Blantika, 2007), 1456.

${ }^{41}$ Yusuf Qardhawi, Taysìr al-Figh li al-Muslim al-Mu'äsharat fi Dhau' alQur'àn wa al-Sunnat...,77.

${ }^{42}$ Lihat, As'ad 'Abd al-Ghānī, Madkhal fì Ilm Ushūl al-Fiqh (Kairo: Jāmi’at al-Azhar Kulliyyāt al-Dirāsat al-Islāmiyyah, 2002), 23.

${ }^{43} \mathrm{Abu} \mathrm{El}$ Fadl, The Great, 182. 
Bagi Salafi, penggunaan akal dalam berbagai permasalahan teologis memiliki batasan sebagai berikut: Pertama, syari'at didahulukan atas akal, karena syari'at itu maksum sedangkan akal tidak. Kedua, akal memiliki kemampuan mengenal dan memahami yang bersifat global, tidak bersifat detail. Ketiga, apa yang benar dari hukum akal pasti tidak bertentangan dengan syari'at. Keempat, apa yang salah dari pemikiran akal adalah apa yang bertentangan dengan syari'at. Kelima, penentuan hukumhukum tafshiliyah (terperinci seperti wajib, haram dan seterusnya) adalah hak prerogatif syari'at. Keenam, akal tidak dapat menentukan hukum tertentu atas sesuatu sebelum datangnya wahyu, walaupun ia dapat mengenal dan memahami baik dan buruk. Ketujuh, balasan atas pahala dan dosa ditentukan syari'at. Kedelapan, janji surga dan ancaman neraka sepenuhnya ditentukan syari'at. Kesembilan, tidak ada ketentuan terhadap Allah yang ditentukan akal kepada-Nya. ${ }^{44}$

Dalam ajaran kelompok Salafi, jalan untuk mengetahui pokok-pokok agama atau akidah serta pembuktiannya berdasarkan wahyu (al-Qur'an dan Hadis). Apa yang telah ditetapkan al-Qur'an dan dijelaskan oleh sunnah harus diterima dan tidak boleh ditolak. Karena menurut kelompok Salafi, akal tidak mempunyai kekuasaan untuk mentakwilkan al-Qur'an atau menafsirkannya atau menguraikannya, kecuali dalam batas-batas yang diizinkan oleh kata-kata (bahasa) yang dikuatkan oleh hadis Nabi. Fungsi akal tidak lain hanya sebagai saksi pembenaran dan penjelasan dalil-dalil al-Qur'an. Hal ini menurut kelompok Salafi dikarenakan adanya kesadaran dan pengakuan akan keterbatasan akal manusia serta luasnya lapangan pembahasan metafisika atau hal-hal yang ghaib (al-Ghaibiyyat), yang jika dipaksakan akan membuat manusia tersesat. ${ }^{45}$

Dengan demikian, pondasi ideologis yang merupakan dasar dirumuskannya doktrin Salafi menyatakan bahwa prinsip-prinsip Islam tidak terletak pada mazhab-mazhab teologis maupun hirarki keagamaan, tetapi pada al-Qur'an dan sunnah. Akibatnya, para pemimpin gerakan ini berpandangan bahwa keyakinan dan

44Jawaz, Syarh, 72.

${ }^{45}$ Sahilun A. Nasir, Teologi Islam: Sejarah, Ajaran, dan Perkembangannya (Jakarta: Rajawali Press, 2010), 284. 
kewajiban agama harus berpijak pada dua sumber pokok tersebut, dan bahwa setiap muslim didorong untuk memahami Islam melalui kedua sumber itu. Mereka percaya bahwa alQur'an mengandung seperangkat ajaran yang sempurna, yang telah dan selalu akan mampu menjawab tuntutan kemanusiaan sejak zaman Nabi Muhammad sampai akhir zaman nanti. ${ }^{46}$

Secara general, kelompok Salafi mempunyai tiga prinsip pengambilan. Pertama, bahwa Islam lewat al-Qur'an dan sunnah Nabi menurut kelompok Salafi telah menyediakan ajaran-ajaran yang cukup lengkap untuk menjawab persoalan kehidupan sepanjang zaman. ${ }^{47}$ Dengan kata lain, jika keseluruhan ajaran tersebut disebut sebagai syari'ah, sebagaimana istilah ini dipahami pada awalnya dan bukan dalam maknanya yang lebih sempit sebagai hukum, maka tidak diperlukan lagi ekstra syari'ah dengan alasan al-Qur'an dan hadis telah cukup. Kedua, mengutip sebuah hadis yang masyhur yaitu apa yang telah diharamkan oleh Islam akan haram sampai akhir zaman, dan apa yang dihalalkan Islam akan halal sampai akhir zaman. Ketiga, ajaran al-Qur'an dan sunnah menurut kelompok Salafi pada dasarnya telah jelas pada dirinya sendiri. Karena itu, al-Qur'an tidak perlu ditafsirkan, apalagi dita'wilkan. Bahkan seperti dikatakan oleh Yazid bin Abdul Qadir Jawaz, mengambil lahiriyah al-Qur'an dan sunnah serta memahaminya secara harfiah atau literal merupakan prinsip dasar Ablussunnah wal Jama'ah. ${ }^{48}$ Lebih dari itu makna al-Qur'an bersifat tunggal, bukan berganda.

Secara umum, karaktristik kelompok ini seperti yang diungkapkan oleh al-Hefnī antara lain pertama, argumentasi harus jelas diambil dari al-Qur'an dan hadis. Kedua, penggunaan akal harus sesuai dengan nash yang shahīh. Ketiga, dalam konteks akidah harus berdasarkan atas naql saja, mereka mempercayai dan hanya menerima teks-teks agama (al-Qur'an dan Hadis) karena ia bersumber dari Allah. Adapun akal, hanya berfungsi sebagai saksi (syāhid) bukan sebagai penentu (ḅäkim). ${ }^{49}$

46 Jawaz, Syarh, 146.

${ }^{47}$ al-Utsaymin, Fath, 42.

48Jawaz, Syarah, 191.

49'Abd al-Mun'im al-Hifni, Mausü'at al-Furūq wa al-Jamā'at wa al-Mazāhib al-Islämiyyat (Kairo: Dar al-Ma'arif, tt.), 246. 


\section{Paham Keagamaan Salafi: Implikasi Perbedaan}

Tidak ada sumber yang secara pasti menyebutkan kapan paham Salafi mulai masuk ke Lombok. ${ }^{50}$ Saat ini paham Salafi sudah menyebar seluruh Nusa tenggara Barat. ${ }^{51}$ Beberapa pesantren tercatat bercorak Salafi antara lain Pondok Pesantren Abu Hurairah, Pondok Pesantren Abu Dzar al-Ghifari, Pondok Pesantren Darus Syifa, dan pesantren al-Madinah.

Kelompok Salafi mempraktekkan kehidupan agama yang didasarkan atas pemahaman yang literalis mengacu kepada apa yang ada di dalam al-Qur'an, hadis dan salafus shalib. Sementara tradisi keagamaan yang dipraktekkan suku Sasak merupakan akulturasi budaya dengan agama. Karenanya, gerakan Salafi agak sulit diterima banyak kalangan di Lombok karena akan mengubah praktek-praktek keagamaan yang telah ada dan mapan. ${ }^{52}$

Dalam berbagai ajarannya, terutama terkait dengan masalah praktek-praktek keagamaan atau keyakinan, kelompok Salafi

${ }^{50}$ Melihat latar belakang tokoh-tokoh Salafi di Lombok, sebagian besar dari mereka adalah lulusan LIPIA dan beberapa universitas di Timur Tengah menguatkan tesis Imdadun bahwa persentuhan awal para aktivis gerakan Salafi di Indonesia dengan pemikiran Salafisme terjadi sekitar tahun 1980-an, bersamaan dengan dibukanya Lembaga Pengajaran Bahasa Arab (LPBA) di Jakarta yang kemudian berganti nama menjadi Lembaga Ilmu Pengetahuan Islam dan Sastra Arab (LIPIA). Menurut Imdadun pembentukan keyakinan, pandangan, sikap dan tindakan yang sesuai dengan ajaran Salafi menjadi orientasi utama dari lembaga ini (LIPIA). Dalam perkuliahan sehari-hari mahasiswa ditekankan untuk memahami, menghayati, dan menghafal materi-materi kuliah yang berbasis paham Salafi. Di kelas, tidak berkembang suasana yang mendorong olah fikir (daya analisa). Sebaliknya, atmosfir indoktrinasi lebih mewarnai perkuliahan. Menurut Imdadun, menyampaikan pemikiran lain apalagi menyangkal ajaran-ajaran utama Salafi, khususnya soal-soal akidah (teologi) sangat tidak dikehendaki. Lihat, M. Imdadun Rahmat, Arus..., 103.

${ }^{51}$ Nashuddin, dkk., Laporan Penelitan, Pemikiran dan Aksi Keagamaan Pondok Pesantren Salafi di NTB, IAIN (Mataram: Lembaga Penelitian IAIN Mataram, 2011).

52Penolakan masyarakat Sasak terhadap dakwah ini hampir terjadi di sebagian besar pulau Lombok. Konflik antara kelompok Salafi terjadi semenjak tahun 2005 hingga yang terakhir tahun 2009 di desa Mesanggok kecamatan Gerung. Tabloid Perspektif, edisi 1 s/d 31 Maret 2009. 
banyak menilai salah terhadap paham atau tradisi yang dianut oleh masyarakat setempat, dan menganggap bid'ah apa yang telah dilakukan secara turun temurun seperti shalat tarawih cukup hanya delapan rakaat, bukan dua puluh rakaat, tidak melakukan dzikir jabr (zikir dengan suara keras), dilarang melakukan perayaan maulid, upacara atau zikir kematian pada hari ketiga (nelung), hari ketujuh (mitu) dan hari kesembilan (nyiwa) serta haram hukumnya memakan makanan yang disediakan pada acara itu.

Di sisi yang lain, masyarakat menganggap kelompok Salafi tidak memperdulikan tentang sejarah masuknya Islam ke Lombok yang dibawa oleh Sunan Prapen. Dalam menyebarkan Islam, Sunan Perapen memanfaatkan unsur budaya yang ada pada masyarakat agar dapat diterima. Sebaliknya, kelompok Salafi mencela budaya masyarakat Sasak seperti ziarah kubur dan ritual-ritual yang terkait dengan kematian sebagai perbuatan sesat (dhalā) dan warisan orang Bali (agama Hindu) yang harus ditinggalkan.

Menurut kelompok Salafi, umat Islam wajib kembali kepada Islam yang dipandang murni, sederhana dan lurus yang diyakini dapat sepenuhnya direbut kembali dengan mengimplementasikan perintah dan contoh Nabi secara literal dan dengan secara ketat mentaati praktek para salaf al-shäliḥ yang benar. ${ }^{53}$

Gerakan ini pada akhirnya mendefinisikan dan mengklaim kelompoknya sebagai Islam itu sendiri, yaitu Islam yang murni dan bebas dari penambahan, pengurangan dan perubahan. Ajaran Salafiyyah menurut mereka adalah ajaran al-Qur'an dan sunnah. Karena itu, gerakan Salafiyyah bukanlah partai politik ataupun mazhab baru, tetapi ajaran Salafiyyah merupakan Islam dalam totalitasnya yang menuntun semua manusia apapun budaya, ras atau warna kulitnya. Ia merupakan metode (manhaj) yang lengkap dan sempurna dalam memahami Islam dan

${ }^{53}$ Yazid bin Abdul Qadir Jawaz, Makna Ablussunnah wal Jama'ah. Lihat juga, Buletin al-Hujjah, vol. II-IX Jumadal Ula 1429 H/Mei 2008 diterbitkan oleh Bidang Dakwah Yayasan al-Hunafa Lombok. Lihat juga, Buletin alI'tisham, Salafiyyah Sesat? Sebuah Catatan tentang Isu Tidak Benar terhadap Dakwah Salafiyyah, vol. 18-19/Rabi'ul Awwal 1430 H/Maret 2009. 
melaksanakan tindakan sesuai dengan ajaran-ajarannya yang murni dan otentik. ${ }^{54}$

Fokus utama kontroversi kelompok Salafi dan masyarakat Sasak di Lombok Barat adalah tentang ritual agama dan ritual adat yang dipraktekkan dan diwarisi selama bertahun-tahun oleh masyarakat Sasak di Lombok. Walaupun pada awalnya kontroversi Salafi hanya terbatas pada pemikiran, tidak jarang juga pada kasus tertentu dibarengi dengan tindakan dan kekerasan. ${ }^{55}$ Sehingga menimbulkan masalah sosial dalam kaitannya dengan kelompok masyarakat Sasak. Meskipun demikian, tidak berarti bahwa tidak ada suara negatif sama sekali terhadap kelompok Salafi, stigma eksklusif dan radikal merupakan lontaran yang kerap dialamatkan masyarakat Sasak terhadap kelompok ini.

Fokus kontroversi yang kerap menjadi perdebatan Salafi Sasak antara lain; Pertama, tablilan (do'a selamat). Istilah "tahlilan" berasal dari bahasa Arab yang berarti membaca là iläha ilallāh. Namun dalam istilah yang berlaku kemudian, pengertian tahlilan adalah kegiatan seseorang atau sekelompok orang untuk membaca serangkaian kalimat. ${ }^{56}$ Umumnya kalimat yang dibaca terdiri dari, pertama, ayat-ayat al-Qur'an, surat al-Fätihaḥ, surat alIkhlās, surat al-Falaq, surat an-Nās, kemudian awal surat al-

54al-Suhaymī, Kun Salafiyyan, 65-71. Lihat juga Rahmat, Arus, 64.

55Beberapa konflik yang terjadi, di antaranya penyerangan dan pengerusakan fasilitas pondok pesantren Ihya al-Sunnah yang menganut paham Salafi di lingkungan Repok Gapuk desa Sekotong Tengah kecamatan Sekotong Lombok Barat. ${ }^{55}$ Konflik ini menurut beberapa warga dipicu oleh perbedaan paham keagamaan dan adat antara masyarakat dan kelompok Salafi. Masyarakat tidak menerima klaim bid'ah kelompok Salafi terhadap ritual dan tradisi keagamaan yang telah mereka amalkan dan membudaya sejak dahulu serta mendapatkan legitimasi dari para tuan guru (ulama) dan tokoh masyarakat setempat. ${ }^{55}$ Kasus yang sama juga pernah terjadi dua kali di Lombok Barat pada November 2005, yaitu di desa Gelogor dan desa Sesela. Ribuan warga desa Sesela menyerbu Yayasan Pondok Pesantren Salafi Ubay bin Ka'ab pimpinan Fathul Aziz di dusun Kebon Lauk. Penyerbuan ini dipicu oleh perbedaan paham dan tradisi tentang talkin saat penguburan orang mati (jenazah) dan doa qunut ketika shalat subuh. ${ }^{55}$ Lihat, Lombok Post, 26 November 2005 dan 17 Juni 2006.

${ }^{56}$ Muhammad Thalhah Hasan, Ablussunnah wal Jama'ah dalam Persepsi dan Tradisi NU..., 238. 
Baqarat, ayat kursi dan dua atau tiga ayat-ayat akhir surat alBaqarat. Kedua, shalawat kepada nabi Muhammad. Ketiga, tahlil atau bacaan là ilāha illallāh. Keempat, tasbih dan tahmid. Kelima, istighfar yaitu meminta ampun kepada Allah untuk diri sendiri maupun untuk orang lain, baik yang masih hidup maupun yang sudah meninggal. Terakhir, doa sesuai dengan tujuan dan konteks di mana tahlilan diadakan.

Kedua, talkin. Menurut ajaran Islam, ada empat hal yang wajib dilaksanakan dalam menguruskan orang mati. Pertama, si mayit harus dibersihkan dan dimandikan. Kedua, si mayit harus dikapankan. Ketiga, si mayit harus dishalatkan. Keempat, si mayit harus dikebumikan. ${ }^{57}$ Dalam prosesi penguburan jenazah, budaya dan tradisi yang berlaku dalam masyarakat Sasak, setelah pengantar jenazah sampai di kuburan merekapun duduk, kemudian membaca surat al-Ikhläs, surat al-Falaq dan surah alNās, jenazah lalu dido'akan dengan berbagai kalimat-kalimat yang baik (kalimat al-thayyibat). Setelah pembacaan surah-surah dan kalimat-kalimat yang baik, kemudian dilanjutkan dengan pembacaan tahlil dan talkin oleh tokoh agama dan diakhiri dengan do'a.

Menurut Imām Hanafị, Imām al-Syāfi'ī dan Imām Aḥmad bin Hanbal, seperti yang diungkapkan oleh 'Abd al-Raḥmān alJazīrì dalam kitabnya al-Figh 'alà al-Mazāhib al-'Arba'at tidak ada teks-teks agama baik al-Qur'an maupun hadis yang secara pasti melarang ataupun menganjurkan untuk mentalkin mayit setelah penguburan. Sebaliknya, Imām Māliki mengatakan bahwa pembacaan talkin setelah si mayit dikubur hukumnya makrūh karena talkin dianjurkan ketika seseorang masih hidup. ${ }^{58}$

Ketiga, Zikir Setelah Shalat. Islam dalam bahasa Arab berarti kepatuhan ${ }^{59}$ dan shalat adalah kewajiban setiap individu muslim yang paling diutamakan. Kewajiban shalat lima waktu disetujui oleh seluruh ummat Islam baik kelompok Salafi maupun

57‘'Abd al-Raḥmān al-Jazīrī, Kitāb al-Fiqh 'alā al-Maẓāhib al Arba'at, Jilid I (Beirut: Dār al-Fikrī, 1972), 500-1. Wawancara dengan Ahmad Khumaidi, tanggal 25 Januari 2010.

${ }^{58}$ al-Jazīrī, Kitāb, 501.

${ }^{59}$ Nurcholish Madjid, Pintu-pintu Menuju Tuhan, (ed.), Eliza Peldi Taher (Jakarta: Paramadina, 1999), 2. 
masyarakat Sasak. Lebih dari itu, shalat berjamaah pada umumnya disepakati lebih utama dari shalat individual. ${ }^{60}$ Kontroversi yang terjadi antara kelompok Salafi dan masyarakat Sasak tidak terletak pada ritual shalat itu sendiri, namun zikir dan doa yang dilakukan setelah shalat. Sikap kelompok Salafi terhadap masyarakat Sasak yang memandang bid'ah ${ }^{61}$ terhadap zikir dan doa yang dilakukan secara jabr (bersuara) dan berjamaah menyinggung perasaan masyarakat Sasak yang telah melakukan ritual ini bertahun-tahun lamanya dan telah diwariskan oleh para tuan guru yang mereka anggap sebagai petuah yang harus diikuti.

Bagi kelompok Salafi, zikir dan doa setelah shalat tidak dilakukan secara jahr (bersuara) dan bersama-sama, namun hanya dilakukan dengan sirr (dalam hati). Menurut kelompok Salafi, zikir seperti inilah yang dianjurkan Islam dalam al-Qur'an dan dicontohkan oleh Nabi dalam berbagai hadisnya. Kelompok Salafi memahami ayat al-Qur'an, "Dan sebutkanlah nama Rabbumu dalam hatimu dengan merendabkan diri dan rasa takut dan dengan tidak mengeraskan suara di waktu pagi dan petang dan janganlah kamu termasuk orang-orang yang lala?". (Qs. al-A'rāf [7]: 205) dan firman Allah, "Berdoalah kepada Rabbmu dengan berendah diri dan tidak mengeraskan suara. Sesunggubnya Allah tidak menyukai orang-orang yang berlebihan" (Qs. al-A'rāf [7]: 55). Menurut kelompok Salafi, suatu ibadah haruslah ditetapkan berdasarkan dalil, baik alQur'an maupun hadis Nabi, ibadah yang tidak didasarkan atas dalil, maka hal itu adalah perbuatan bid'ah. Ini mereka dasarkan pada hadis Nabi, "Barang siapa yang mengamalkan sesuatu yang tidak sesuai dengan urusan agama kami, maka amalnya tertolak.". 62

${ }^{60}$ Dalam suatu hadis yang diriwayatkan oleh Imām al-Bukhārī dalam kitabnya menyatakan bahwa rasulullah mengatakan, "Shalat jama'ab lebih utama dari shalat pribadi dengan dua pulub tujuh derajat”. Lihat, Imām al-Bukhārī, Shạ̄in al-Bukhārī, Kitāb al-Ādzān, no. 609. (CD ROOM).

${ }^{61}$ Tokoh-tokoh Salafi di Lombok sepakat menyatakan dalam setiap pengajian yang mereka adakan bahwa zikir jahr adalah bid'ah. Di antara rujukan mereka adalah kitab al-Tawhid karya Muhammad bin 'Abd alWahhāb, kitab al-Bid'at; Ta'rîfuhā 'Anwāuhā wa Aḅkāmuhā karya Syekh Shāliḥ bin Fauzān al-Fauzān yang diterbitkan oleh Dār al-'Aqīdaṭ Makkah dan Sittu Durar min Ushül Abl al-Atsar karya 'Abd al-Mālik bin Aḥmad Ramdhānī.

'2Lihat, Imām al-Bukhārī, Shaḥị̣ al-Bukhārì, Kitāb al-Buyū’ (CD ROOM). 
Keempat, tawassul. Tawassul berasal dari akar kata al-wasilat yang berarti sebab yang menyampaikan pada tujuan. ${ }^{63}$ Tawassul adalah suatu usaha atau jalan yang ditempuh seseorang dalam mendekatkan diri kepada tuhan, untuk mendapatkan tempat yang mulia di sisinya. Kebanyakan mufassir menafsirkan kata wasilah dengan amal shaleh, jalan atau sarana yang dipakai oleh seseorang untuk dekat kepada Allah. Jalan itu adalah memperbanyak ibadah, berbuat kebajikan, menegakkan budi pekerti yang tinggi dan belas kasihan terhadap sesama. Tawassul kepada Allah adalah mengambil suatu sarana demi terkabulnya doa. Tawassul dalam berdoa kepada Allah adalah bahwa orang yang berdoa, mengiringi doanya dengan sesuatu yang menjadi sebab bagi diterimanya doa tersebut. ${ }^{64}$

Tawassul dalam Islam terbagi menjadi tawassul yang diperbolehkan dan tawassul yang tidak diperbolehkan. Pertama, tawassul yang diperbolehkan antara lain bertawassul kepada Allah dengan asma' dan sifatnya, bertawassul kepada Allah dengan iman dan amal saleh yang dilakukan oleh orang yang bertawassul dan tawassul kepada Allah dengan doa orang saleh yang masih hidup. Kedua, tawassul yang tidak diperbolehkan seperti meminta doa kepada orang mati, tawassul dengan kedudukan Nabi. ${ }^{65}$

Ibn Taymiah mengatakan bahwa ummat Islam boleh bertawassul kepada Nabi Muhammmad baik ketika masih hidup maupun setelah meninggal. Sedangkan menurut Muhammad bin

${ }^{63}$ Menurut al-Fairuzabādī, yang dimaksud dengan al-wasilat secara bahasa adalah berperantara kepada Tuhan dengan suatu perantara, yaitu melakukan suatu perbuatan yang mendekatkan dirinya kepada Tuhan. Lihat Fairuzabādī, al-Qāmūs al-Mubìth (Kairo: Musthafā al-Bāb al-Halabī wa Awlāduh, 1952), jilid 4, 552. Dalam kitab Lisān al-'Arab, Ibn Manzūr memaknai al-washilat sebagai al-qurbat (pendekatan). Makna si fulan berperantara kepada Allah dengan suatu wasilah adalah melakukan suatu perbuatan untuk mendekatkan diri kepada Tuhannya. Ibn Manzūr, Lisān al 'Arab (Beirut: Matba'aṭ Dār al-Fikr, 1990 M/1410 H), jilid 11, 724.

${ }^{64} \mathrm{Abū}$ Anas 'Al̄̄ bin Husayn Abū Luz, al-Tawassul: Aqsāmubu wa Aḅkāmubu, ter. Muhammad Iqbal Amrullah, Tawassul Sunnah Vs Tawassul bid'ah (Jakarta: Darul Haq, 2007), 11.

${ }^{65}$ Shālih bin Fawzān bin Abdullāh al-Fauzī, at-Tawhìd, ter. Ainul Haris Umar Thayib, Kitab Tawhid (Jakarta: Yayasan Al-Sofwa, tt.), 86. 
'Alī al-Syawkānī berpendapat bahwa boleh bertawassul dengan nabi atau selain nabi seperti orang saleh atau wali. ${ }^{66}$

Dalam masyarakat Sasak, tawassul sering muncul dalam fenomena ziarah kubur, zikir dan doa. Ziarah kubur sudah menjadi tradisi dalam masyarakat, biasanya mereka mengunjungi kubur atau makam tuan guru atau makam wali yang dikeramatkan.

Keenam, Maulid Nabi. Maulid Nabi di Lombok merupakan ritual yang cukup unik. Selain acara maulid yang diadakan di masjid-masjid dengan mengundang kiai-kiai dari desa-desa lain, setiap rumah mengadakan acara maulid sendiri-sendiri, dengan mengundang sanak saudara atau sahabat dari daerah lain. Setiap dusun atau desa menyelenggarakan perayaan maulid pada hari dan tanggal yang berbeda. Penyelenggaraan hari dan tanggal maulid ini berdasarkan musyawarah para tokoh masyarakat. Menurut pengamatan penulis hampir satu bulan lamanya masyarakat Sasak di Lombok menyelenggarakan acara ini dengan intesitas kemeriahan yang beragam.

Acara maulid sering menjadi kontroversi antara kelompok Salafi dan masyarakat Sasak. Acara yang sudah turun temurun dilaksanakan dan sarat dengan nilai adat dan budaya ini dinilai oleh kelompok Salafi sebagai pemborosan. Dalam pandangan kelompok Salafi, acara maulid Nabi dan acara-acara lainnya seperti peringatan isra' mi'raj, nuzulul Qur'an, dan lain-lainnya adalah fenomena baru dalam agama atau perkara baru (bid'ah). Acara seperti ini tidak pernah dikerjakan oleh nabi, para sahabat, täbi'in, tabi al-täbiìn dan para ulama terpandang seperti imam madzhab yang empat. ${ }^{67}$

Ketujuh, Nyongkolan. Perkawinan dalam adat Sasak memakan waktu yang cukup panjang, karena berbagai prosesi yang dilalui. Seperti selabar, sorong serah, aji krame dan lain-lain. tetapi dari

${ }^{66}$ Muhammad 'Alwī al-Mālikī, Mafāhim Yäjib an Tushahhat, ter. Indri Mahally Fikri, Paham-Paham yang Perlu Diluruskan (Jakarta: Fikahati Aneska, 1994), 170.

${ }^{67}$ Lihat: Ibrāhim Muḥammad bin 'Abdullāh al-Buraykan, al-Madkhal li Dirāsat al-'Aqìdat al-Islāmiyyat 'alā Madz̧habi Abl al-Sunnat wa al-Jamā'at, ter. Muhammad Anis Matta, Pengantar Studi Aqidab Islam (Jakarta: Rabbani Press, 1998), 332-3. 
berbagai prosesi yang ada, nyongkolan merupakan tema yang paling sering menjadi fokus pembicaraan kelompok Salafi di Lombok Barat.

Kedelapan, Ngurisan, yakni sebuah prosesi menyambut kelahiran seorang bayi. Biasanya acara ini dirangakai dengan acara aqiqah dan dilakukan satu minggu sampai dua bulan dari kelahiran bayi. Pada acara ini keluarga mengadakan jamuan makan dan mengundang kerabat. Para undangan duduk melingkar, ketika pembacaan slakaran ${ }^{68}$ dimulai, undangan dipersilahkan untuk berdiri. Seorang laki-laki (biasanya ayah atau kakek si bayi) mengendong bayi tersebut dan berjalan berkeliling orang-orang yang sedang slakaran. Masing-masing tamu memotong rambut si bayi. Setelah acara selesai barulah makanmakan (roah) dimulai.

Berbagai macam ritual ini walaupun terlihat terkait dengan permasalahan hukum atau fikih, namun jika kita telusuri lebih jauh dan mendalam, sesungguhnya sangat terkait dengan permasalahan keyakinan akan eksistensi tuhan dan eskatologi atau kehidupan setelah kematian. Menurut kelompok Salafi, keyakinan apapun jika tidak berdasar pada al-Qur'an, hadis dan praktek para salaf al-shälih maka dianggap bid'ah dan kesesatan. Apalagi jika hanya bersandar pada kultur dan budaya lokal.

\section{Catatan Akhir}

Kelompok Salafi seperti halnya umat Islam pada umumnya sepakat tentang ajaran Islam yang tertuang dalam al-Qur'an maupun hadis, meyakini dan menerimanya merupakan aspek mendasar keyakinan yang akan membedakan antara seorang muslim dan non muslim. Hanya saja, dalam memahami ajaran tersebut, kelompok Salafi lebih bersifat literalis dan membatasi peran akal. Di samping itu kelompok Salafi menutup mata

${ }^{68}$ Selakaran adalah suatu ritual adat yang dilakukan oleh masyarakat Sasak di mana mereka memuji dan membacakan tentang hidup dan sejarah perjuangan Nabi Muhammad dengan nada-nada tertentu. Kitab yang dijadikan rujukan adalah Kitab Majmu' Maulid Wadì'at atau yang dikenal dengan nama Kitab Berjaņ̃ karya Imām Jalīl 'Abd al-Rahmān al-Daybī (Semarang: Maktabah wa Matba’ah Qaryah Putra, tt.). 
terhadap berbagai pemahaman keagamaan di luar kelompok mereka termasuk pemahaman keagamaan masyarakat Sasak.

Dalam perspektif Salafi, pemahaman seperti penyelenggaraan beberapa upacara yang berhubungan dengan daur/lingkaran hidup (life cycle) manusia yang dimulai dari peristiwa kelahiran hingga kematian merupakan unsur baru yang mereka sebut bid'ah dan keharusan bagi Salafi untuk melakukan purifikasi keagamaan di tengah masyarakat Sasak. Selama perbedaan-perbedaan konsep keagamaan masih ada maka potensi konflik antara Sasak dan Salafi masih terus ada, diperlukan sikap saling menghargai dan tenggang rasa agar potensi tersebut tidak muncul menjadi konflik terbuka. Wa alLäh a lam bi al-sawāb.

\section{Daftar Pustaka}

'Abd al-Wahhāb, Muhammad bin. 1382 H. Kitāb al-tawhìd. Riyadh: Mu'assasat al-Nūr li al-tibā'aṭ wa al-tajlīd.

'Abd al-Halīm al-Jundī. 1986. Muhammad bin 'Abd al-Wabhāb aw Intishār Mažhab al-Salafì . Kairo: Dār al-Ma'ārif.

'Abdullāh al-Buraykan, Ibrāhīm Muḥammad. al-Madkhal li Dirāsat al-'Aqìdat al-Islämiyyat 'alā Madð̧hab Abl al-Sunnat wa al-Jamäat. ter. Matta, Muhammad Anis. 1998. Pengantar Studi Aqidah Islam. Jakarta: Rabbani Press.

Abū Zahraț, Muhammad Aḥmad. tt. Al-Mazāhib al-Islämiyyat. Mesir: al-Matba'at al-Namūjaziyaț.

Abdul Qadir Jawaz, Yazid. 2004. Syarh Aqidah Ablussunnah wal Jama'ah. Bogor: Pustaka Imam al-Syafi'i.

Abū Hasan al-Atsarī. 2012. Al-Bid'at Musthalahuhā wa 'Anwāủāà. Saudi Arabia: Matba'aṭ al-Ashālaṭ al-Atsariyyaṭ.

Abū Luz, Abū Anas 'Alī bin Husayn. Al-tawassul: Aqsāmubu wa Aḅkāmubu. ter. Muhammad Iqbal Amrullah. 2007. Tawassul Sunnah Vs tawassul bid'ah. Jakarta: Darul Haq.

Abou El Fadl, Khaled. The Great theft: Wrestling Islam from the Ekstrimists. ter. Helmi Musthafa. 2005. Selamatkan Islam dari Muslim Puritan. Jakarta: Serambi Ilmu Semesta.

'Abd al-Halīm al-Jundī. 1986. Muhammad bin 'Abd al-Wabhāb aw Intishār Maz̧ab al-Salafì . Kairo: Dār al-Ma’ārif. 
Aḥmad Ramdhānī, 'Abd al-Mālik bin. Sittu Durar min Ushūl Abl al-Atsar. ter. Mubarak Bamu'allim. 2005. Enam Pilar Dakwah Salafiyyah. Surabaya: Pustaka Imam al-Syafi'i.

'Alī Sāmī al-Nasyār. tt. Nasy'at al-Fiker al-Falsafi fì al-Islām. Cet. 2. Kairo: Dār al-Ma'ārif.

Amin, Ahmad, et.al.. 1997. Adat Istiadat Daerah Nusa tenggara Barat (NTB). Jakarta: Departemen Pendidikan dan Kebudayaan RI.

Atjeh, Aboebakar. 1970. Salaf (Salaf al-Sälib) Islam dalam Masa Murni. Jakarta: Perma.

al-Asy'arī, Abū al-Hasan ibn Ismā'il. tt. Al-Ibānaț fì Ushūl alDiyanat. Hyderabad: tp.

'Azami, M.M. 1981. Dirāsat fi al-Hadits al-Nabawi wa tārikeh tadwinibi. ter. Subḥ̄ Sālih, Ulūm al-Hadìts wa Musthalabubu 'Ardun wa Dirāsat. Beirut: Dār al-'Ilm li al-Malāȳin.

al-Bukhārī, Imām. Shahịh al-Bukhārì, Kitāb al-Ādzān. No. 609. (CD ROOM).

Farīd, Aḥmad dan Sāleh al-Fawzān. al-Salafiyyat Qawāid wa alUshūl: Ta'qibat 'alā Kitāb al-Salafiyyat Laisat Maz̧haban. ter. Muhammad Muhtadi. 2009. Polemik Salafi. Solo: Multazam.

Budiwanti, Erni. 2000. Islam Sasak Wetu Telu Versus Waktu Lima. Yogyakarta: LKiS.

Fairuzabādī. 1952. Al-Qāmūs al-Mubìth. Jilid 4. Kairo: Musthafā al-Bāb al-Ḥalabī wa Awlāduh.

Al-Faruqi, Ismail R. dan Lois Lamya al-Faruqi. 2000. Atlas Budaya Islam. Bandung: Penerbit Mizan. . 1988. Tawhid. Bandung: Penerbit Pustaka.

Fawzān, Shālih bin. At-tawhìd. ter. Ainul Haris Umar Thayib. tt. Kitab Tawhid. Jakarta: Penerbit Yayasan Al-Sofwa.

al-Ghazāīi, Imām. 1962. al-Iqtishād fì al-I'tiqād. Mesir: Maktabat Muhammad Subayh.

al-Hifni, 'Abd al-Mun'im. tt. Mausū'at al-Furūq wa al-Jamä'at wa al-Mažāhib al-Islāmiyyat. Kairo: Dar al-Ma'arif.

Ibn Manzūr. 1990. Lisān al 'Arab. Jilid 11. Beirut: Matba'aṭ Dār al-Fikr.

Imārah, Muhammad. 1995. Thayyārat al-Fiker al-Isläm. Kairo: Dār al-Syurūq. 
Jamhari dan Jajang Jahroni (ed.). 2004. Gerakan Salafi Radikal di Indonesia. Jakarta: PT. Raja Grafindo Persada.

al-Khatīb, Muhammad 'Ajaj. 1409 H. Ushül al-Hadìts Ulümubu wa Musthalahuhu. Beirut: Dār al-Fikr.

Lembaga Penelitian dan Pengkajian WAMI. al-Mausü'at alMuyassart fì al-Adyān wa al-Mazāhib al-Mu'äshirat. ter. A. Najiuyulloh. 1995. Gerakan Keagamaan dan Pemikiran: Akar Ideologis dan Penyebarannya. Jakarta: al-Islahy Press.

Madkūr, Ibrāhīm. tt. Fì al-Falsafat al-Islämiyyat Manbajubu wa Thatbìqubu. Kairo: Dār al-Ma'ārif.

Madjid, Nurcholish. 1999. Pintu-Pintu Menuju Tuban. (Ed.) Eliza Peldi Taher. Jakarta: Paramadina.

al-Mālikī, Muḥammad 'Alwī. Mafähim Yäjib an Tushabhat. Ter, Indri Mahally Fikri. 1994. Paham-Paham yang Perlu Diluruskan. Jakarta: Penerbit Fikahati Aneska.

Muttahari Murtadha. 1985. Pandangan Dunia Tawbid. Bandung: Penerbit Mizan.

Nashuddin, dkk. 2011. Laporan Penelitan. Pemikiran dan Aksi Keagamaan Pondok Pesantren Salafi di NTB. Mataram: Lembaga Penelitian IAIN Mataram.

Nasir, Sahilun A. 2010. Teologi Islam: Sejarah, Ajaran, dan Perkembangannya. Jakarta: Rajawali Press.

al-Nasyār, 'Alī Sāmī. 1981. Nasy'at al-Fiker al-Falsafì fì al-Islām. Cet. 3 Jilid 1. Kairo: Dār al-Ma'ārif.

Qardhawi, Yusuf. Kebangkitan Gerakan Islam: Dari Transisi Menuju Kematangan. ter. Abdullah Hakam Syah dan Ainul Abied Syah. 2003. Jakarta: Pustaka Al-Kautsar.

Rahmat, M. Imdadun. 2005. Arus Baru Islam Radikal: Transmisi Revivalisme Islam Timur Tengah ke Indonesia. Jakarta: Penerbit Erlangga.

Schwartz, Stephen Sulaiman. The Two Face of Islam: Studi Fundamentalism and Its Role in Terorism. ter. Hodri Ariev. 2007. Dua Wajah Islam Modernisme vs Fundamentalisme dalam Wacana Global. Jakarta: Penerbit Blantika.

Sihab, M. Quraish. 2000. Wawasan al-Qur'an. Bandung: Penerbit Mizan.

Penerbit Mizan. . 1998. Membumikan al-Qur'an. Cet. 17. Bandung: 
Tholkhah, Imam. Gerakan Islam Salafiyah di Indonesia. Jurnal Edukasi. Vol 1. No. 3. Juli-September 2003.

al-'Utsaymin, Muhammad bin Shālih. Fath Rabb al-Bariyyat bi Talkhish al-Hamawiyyat. ter. Hammad bin "Amir Abu Mu'awiyah. 2009. Aqidah Muslim dalam Tinjauan al-Qur'an dan al-Sunnah. Bekasi: Maktabah Dar el Salam.

Lombok Post, 25 November 2005.

tabloid Perspektif. Edisi, 1 s/d 31 Maret 2009.

Buletin al-I'tisham. Nikmat Islam. Edisi 18 Shafar 1431 H/Januari 2010. 